\title{
DISKURSUS INDO-PASIFIK: HEGEMONI AMERIKA, PERSAINGAN STRATEGIS, HINGGA TRANSFORMASI GEOPOLITIK KAWASAN
}

\author{
Sony Iriawan \\ Universitas Pertahanan \\ Email: Soni.irawan19@gmail.com
}

\begin{abstract}
Abstrak
Pernyataan Donald Trump "You Say Asia-Pacific, I Say "Indo-Pacific" menjadi isyarat bagi perubahan geopolitik dunia dimana menandakan perubahan fundamental terhadap politik global dunia. Sebagai diskursus Indo-Pasifik menuntut bentuk perubahan secara mendasar tentang bagaimana memahami dinamika politik internasional yang sebelumnya dikenal dengan sebutan Asia-Pasifik. Penekanan terhadap praktik hegemoni, persaingan strategis, hingga transformasi geopolitik kawasan merupakan cakupan utama yang kemudian tercipta dari proyeksi grand strategy AS. Adapun Indo-Pasifik yang pada intinya merupakan perluasan cakupan geografis dengan melibatkan India sebagai simbol kekuatan dominan di Samudera Hindia menjadi langkah progresif AS guna menghadirkan hambatan struktural terhadap dominasi kekuatan militer Tiongkok.
\end{abstract}

Kata Kunci: Indo-Pasifik, Geopolitik, Hegemoni, Kebangkitan Tiongkok.

\begin{abstract}
Based on Donald Trump's statement "You Say Asia Pacific, I Say" Indo Pacific" became a hint for the changing geopolitics of the world which marks a fundamental change to global politics. The discourse of Indo-Pacific demands a fundamental shift in how to understand the dynamics of international politics, formerly known as AsiaPacific. The emphasis on hegemonic practices, strategic competition, to geopolitical transformation of the region is the main scope that is then created from the projection of the US grand strategy. The Indo-Pacific is essentially an expansion of geographical coverage by involving India as a symbol of the dominant force in the Indian Ocean into a progressive US move to present structural obstacles to the dominance of Chinese military power.
\end{abstract}

Keywords: Indo-Pacific, Geopolitics, Hegemoni, and The Rise of China 


\section{Pendahuluan}

Untuk pertama kalinya, istilah Indo-Pasifik diperkenalkan oleh Perdana Menteri Jepang Shinzo Abe pada forum Quadrilateral Security Dialogue (QSD) pertama tahun 2007. Menjadi sebuah terminologi yang marak menjadi perbincangan akhirakhir ini. AS dalam QSD yang digelar pada 12 november 2017 di Manila mengangkat Indo-Pasifik sebagai istilah baru yang tidak hanya mengganti Asia-Pasifik secara penyebutan maupun cakupan geografis, namun juga perluasan aktor, kekuasaan hingga arsitektur keamanan kawasan (Escobar, 2017). Bersama dengan India, Australia, dan Jepang, AS menekankan bahwa selain perbaikan pada sektor keamanan kawasan, Indo-Pasifik didalamnya juga mengarah pada penciptaan iklim kerjasama yang lebih terbuka. Menandai tahapan awal menuju transformasi geopolitik di kawasan, Istilah Indo dalam hal ini menjadi layaknya "golden tiket" bagi India guna menandakan era baru perluasan peran India dalam landskap tata kelola tatanan kawasan Asia-Pasifik.
Paltform QSD, sama halnya menghadirkan aktor baru dimana terjadi unifikasi kekuatan antara dua samudara yakni Pasifik dan Hindia. Dalam Buku Putih Pertahanan Australia tahun 2013, dikatakan bahwa istilah Indo-Pasifik merupakan terminologi baru dari perkembangan politik internasional yang menghubungkan dua letak geografis yang berbeda antara Samudera Pasifik dan Hindia. Australia bahkan Asia Tenggara menjadi penghubung strategis yang menjembatani "jurang" kepentingan AS dalam mendesak peran lebih India terhadap wilayah yang sebelumnya lebih dikelan dengan sebutan Asia-Pasifik. Dalam pandangan sejumlah akademisi ide yang tertuangan dalam Indo-Pasifik bukanlah hal yang baru, walaupun tidak secara ekplisit menyebutkan Indo-Pasifik, namun alternatif mengikutsertakan samudera Hindia secara geografis dalam mengamankan kepentingan AS menjadi bukti akan pertimbangan strategis AS (Upadhyay, 2014).

Mengikutsertakan India dalam dinamika politik di Asia-Pasifik 
merupakan simbol akan rekonsiliasi power di kawasan dengan melebur dua fitur geografis yang berbeda namun dalam mekanisme keamanan yang serupa (Godbole, 2017). Terlepas dari kepentingan hegemoni AS dibalik terminologi Indo-Pasifik, QSD mengawali sebuah respon jangka panjang mengenai poryeksi struktur keamanan kawasan. Melalui terminologi Indo-Pasifik, AS menjadikan hal tersebut sebagai pijakan utama dalam mendorong kawasan yang inklusif guna mengakomodasi kepentingan jangka panjang seluruh negara di kawasan. Dengan demikian, tujuan daripada penulisan paper ini adalah tentang bagaimana memformulasikan sebuah jawaban terkait beragam pertanyaan mengenai apa kepentingan AS dibalik grand Design Indo-Pasifik, lantas mengapa upaya rekonsiliasi power dengan menambahkan keterlibatan India sebagai representatif dari kekuatan dominan dikawasan menjadi hal yang utama, terakhir tentang bagaimana polarisasi perubahan pembagunan masa depan geopolitik kawasan, hingga bagaimana dengan posisi AS ketika berhadapan dengan ancaman kebangkitan China sejak digelorakanya diskursus Indo-Pasifik.

\section{India Dalam Struktur Keamanan} Indo-Pasifik

Peran aktif India sejauh ini dalam The India-Japan civilian nuclear cooperation agreement, Japan-India maritime security partnership latihan gabungan Indo-U.S Malabar Exercise menjadikan India penting dalam penguatan hubungan bilateral dengan sejumlah great power sebelumnya yaitu di Asia-Pasifik (MoD, 2015). Berakhirnya Perang Dingin 1990an yang kemudian ditandai dengan keruntuhan UniSoviet, menjadi titik awal penigkatan kerja sama AS-India di bidang ekonomi perdagangan maupun keamanan dan pertahanan. Demokrasi hingga kebijakan global AS antiterrorisme menjadikan India sebagai salah satu titik sentral yang mendukung bagi kepentingan AS di Samudera Hindia. Kerjasama maritim AS-India pertamakalinya digelar melalui Bilateral Malabar naval Exercises pada tahun 1992. Kerja sama yang terus berlanjut, hingga pasca 
tragedi 9/11. Mendukung kebijakan global AS Global War on Terror (GWOT), India memberikan lisensi kepada kapal-kapal perang AS selama memerangi rezim Taliban dan kelompok terroris Al-Qaeda di Afganistas yang kemudian berlanjut ke perang Irak yang meruntuhkan rezim Sadam Husein diduga memiliki senjata nuklir dan rezim pendukung kelompok teroris (Dar \& Kalis, 2013).

Kaitannya dengan Indo-Pasifik, pelibatan India di dalamnya secara garis besar didukung oleh banyak para analis serta akademisi Australian dan AS. Melalui QSD negara pendukung tersebut memperkenalkan apa yang dimaksud dengan Indo-Pasifik sebagai bentuk transformasi kawasan yang menunjang bagi peningkatan kerja sama ekonomi hingga pembentukan arsitektur keamanan kawasan dengan melibatkan India sebagai cakupan perluasan geografis dan representasi kekuatan dominan di Samudera Hindia. Dengan demikian penguatan kerja sama selanjutnya antara IndiaJepang, India-Australia menandai eksistensi India dalam konstelasi IndoPasifik (Upadhyay, 2014). Dengan demikian India menempati perannya sebagai proxy AS atas jaminan keamanan di rute transportasi maritim menuju Samudera Hindia (Scott, 2012).

Kemudian keikutsertaan Jepang dalam Malabar Exercises sejak tahun 2012 merupakan bentuk pendalaman kerjasama keamanan maritim antara AS-India dan Jepang. Hal tersebut mengindikasikan bahwa ketiga negara telah mempersiapkan diri menghadapi skema balance of power yang telah lama sebelumnya mendominasi geopolitik kawasan Asia-Pasifik sejak fenomena kebangkitan Tiongkok. Mengawali keikutsertaan Jepang dalam kerja sama keamanan maritim, bersama India dan AS, negeri matahari tersebut menyetujui bentuk komitmen nyata dengan mendukung pencapaian IndoPasifik sebagai upaya balance of power terhadap Tiongkok. Tidak dapat dikesempingkan bahwa dominasi militer Tiongkok seperti di LCS dan Laut Timur telah menimbulkan ancaman terhadap stabilitas keamanan kawasan. Setelah memperdebatkan kembali status quo di LCS, Tiongkok 
telah secara sepihak melakukan supermasi wilayah udara dengan mendeklarasikan Air Defense Identification Zone (ADIZ) tepat di wilayah udara pulau Senkaku/Diaoyu yang sampai dengan saat ini masih berstatus sengketa dengan Jepang (Rinehart \& Elias, 2015) .

Berlanjut pada mega proyek global One Belt One Roots (OBOR), Tiongkok kini memperkuat kerja sama dengan memperkuat kemampuan Angkatan Laut Sri Lanka, Myanmar, Pakistan, Bangladesh. Kerja sama tersebut tersebut tidak lain merupakan strategi deterrence Tiongkok guna mengimbangi dominasi militer India di Samudera Hindia. Mendukung kemajuan militer negara-negara yang terbilang bersebrangan dengan India khususnya Pakistan merupakan bentuk proxy Tiongkok guna menghadirkan perimbangan kekuatan di Samudera Hindia (Ghosh, 2017). Tidak dipungkiri bahwa pertumbuhan pengaruh Tiongkok di kawasan merupakan faktor utama yang mendorong pentingnya langkah strategis ketiga negara AS-India dan Jepang menyiasati kembali strukturisasi keamanan kawasan. Melalui Indo-Pasifik, ketiga negara tersebut menformulasikan langkah antisipasi terhadap ancaman keamanan khususnya terhadap domain maritim (Miller, 2017).

Perdana Menteri India Narendra Modi dalam pertemuan pertama U.S-India summit meeting sejak terpilihnya Trump sebagai presiden AS juni 2017 lalu, menegaskan bahwa diperlukan perluasan kerja sama yang juga menyasar pada pembentukan geopolitik kawasan. Hal tersebut mengingatkan kembali pada apa yang sebelumnya ditawarkan oleh Perdana Menteri Jepang Shinzo Abe dalam kunjungan kenegaraan di India tahun 2007 lalu. Kesamaan konteks geografis, layaknya sebuah konfigurasi yang terjadi secara alamiah dimana baik India maupun Jepang berada pada titik pusat dua Samudera yakni Pasifik dan Hindia (Miller, 2017) . Dengan demikian pembahasan mengenai saling keterhubungan dalam domain maritim menumbuhkan kesadaran akan pentingnya kedua negara untuk melakukan kerja sama "lintas- 
samudera". Kemudian joint statement mempolarisasi pembentukan aliansi strategi Jepang dan India dalam meyambut baik "Open and Free IndoPacific Region". Sebagai bentuk konfigurasi mendalam dimana baik India maupun Jepang terlibat dalam perluasan mekanisme kerja sama, bersama AS keduanya mendukung transformasi struktural mengenai geopolitk kawasan. Perubahan istilah Asia-Pasifik menjadi Indo-Pasifik secara tidak langsung merupakan bagian dari "ratifikasi" struktural terhadap eksistensi India (MOFA, 2017).

Memahami arti penting IndoPasifik sebagai diskursus, maka selanjutnya yang hendak diwujudkan oleh AS-India dan Jepang ialah mengarah pada terciptanya gambaran kondisi geopolitik dunia yang stabil dengan memberikan kesempatan bagi setiap negara guna berkontribusi di dalamnya. Meski sempat mengalami perubahan politik, penigkatan hubungan trilateral terus berkembang sejak 2015 dan meningkatkan fokus mereka terutama pada masalah keamanan maritim (Ghosh, 2017).
Domain maritim menandakan bahwa poros Washington-New-Delhi-Tokyo tersebut menghendaki Indo-Pasifik sebagai kawasan yang bebas dan terbuka. Disamping itu, penekanan terhadap hukum inernasional menjadi basis utama sebagai karekteristik arsitektur keamanan kawasan sehingga memaksa setiap aktor negara untuk mematuhi aturan hukum yang berlaku. Mekanisme yang terciptanya tentunya menjadi basis ide guna menegaskan kembali pentingnya bebas bernavigasi dan penerbangan terbuka sebagai penunjang arus bebas perdagangan di seluruh dunia, termasuk di LCS (Miller, 2017).

Dengan ini India meninggalkan pola terdahulu dimana hubungan diplomatik dengan negara yang sebelumnya dikenal dengan sebutan Asia-Pasifik sebagian besar hanya sebatas kemitraan yang sifatnya informal baik dalam bentuk bilateral maupun multilateral. Trilateralisme AS-India dan Jepang ditambah dengan QSD bersama Australia memungkinkan India untuk menumbuhkan perspektif otonom guna menghubungkan India dengan 
tetangga terdekat di Pasifik yakni Malaysia, Indonesia, Vietnam, Korsel, Salandia Baru, hingga Rusia. Kemudian FOIP. menuntut agar keterlibatan India di Indo-Pasifik juga berbasis pada kekuatan ekonomi, investasi, guna saling meningkatkan ketergantungan dalam meyinkapi peluang kerja sama ekonomi di kawasan. Dengan demikian India akan sangat berpotensi dalam memainkan peranan penting bagi AS guna mencegah pengaruh Tiongkok di Asia (IDSA, 2016). Sudah menjadi rahasia umum jika India sebagai representasi kekuatan di Samudera Hindia, juga menjadi kepanjangan dari kepentingan AS. Sebut saja Indian Ocean Region Enunciated 2015 yang kemudian dilanjutkan dengan The US-India Joint Strategic Vision, hingga kunjungan Menteri Pertahanan AS ke India pada tahun 2016 lalu, tidak hanya menggambarkan langkah kooperatif AS, namun juga bentuk dari proyeksi masa depan Indo-Pasifik. Dimana AS tetap dalam prinsip menjaga kepentinganya di LCS dengan mengupayakan freedom of navigation dan overflight walaupun ditengah persaingan strategis dengan Tiongkok (TheWhiteHouse, 2018).

Khususnya dalam waktu dekat ini, fokus India tetap pada tantangan dan ancaman terhadap isu-isu keamanan non-tradisional yang merupakan bagian penting ketika menentukan sikap dalam menghadapi konstelasi politik di Indo-Pasifik. Pertarungan strategis AS-Tiongkok yang sebelumnya mendominasi lanskap geopolitk Asia-Pasifik pada kenyataannya telah menyisahkan banyak pekerjaan rumah yang harus segera terselesaikan. Hal tersebut seolah mengesampingkan urgensitas utama yang diperlukan seperti peningkatan terhadap pengamanan rute perdagangan yang melintasi Samudera Hindia dan Pasifik Barat (P.K.Ghosh, 2014). Atas inisiatif India Regional Cooperation Agreement on Combating Piracy and Armed Robbery against Ships in Asia (ReCAAP) dibentuk untuk mengajak seluruh stake holders peduli terhadap ancaman pembajakan dan perampokan Bersenjata di laut. Selain itu Angkatan Laut India telah menggagas kerja sama regional terhadap penanganan bencana, 
penyelundupan narkotika, imigran gelap, hingga teroris dan penyelundupan senjata yang keseluruhannya dibahas dalam The Indian Ocean Naval Symposium (IONS). Bersama dengan Tiongkok, India juga aktif dalam koordinasi angkatan laut baik secara bilateral maupun trilateral dengan menggelar joint patrol dengan Jepang, Kenya, Madagaskar dan Seychelles di Afrika. Selain itu, peran India semakin diperluas melalui keikutsertaannya dalam Rim-Association for Regional Cooperation (IOR-ARC), sebuah organisasi kawasan yang dibentuk untuk meningkatkan kerjasama atar 36 negara pesisir dan 11 negara pedalaman khususnya di kawasan Indo-Pasifik (Basu, 2016 ).

\section{Grand Strategy AS Dibalik} Diskursus Indo-Pasifik

Makna perluasan aktor dalam diskursus Indo-Pasifik menggambarkan pendekatan yang lebih terintegrasi. Tidak hanya sebatas proxy, keberadaan India memberikan jaminan terhadap eksistensi hegemoni AS ditengah ancaman kebangkitan Tiongkok. Mempertahankan pengaruh di Indo-Pasifik merupakan bagian sentral dari grand strategy AS. Sebagai dasar utama negara, grand strategy AS merupakan upaya perlindungan terhadap integrasi wilayah, kedaulatan, hingga eksistensinya di kancah global. Status negera hegemon, grand strategy AS termasuk didalamnya soal penguasaan serta mencegah kembali munculnya bentuk-bentuk ancaman terhadap tatanan global yang berusaha menghadirkan kembali tatanan balance of power. Selanjutnya adalah mencerminkan kepentingan nasional dalam hal ini menyebarluaskan tatanan politik liberal internasionalisme dengan mendorong negara-negara di dunia untuk mengadopsi nilai-nilai tersebut sebagai landasan sistem kehidupan bernegara. Terakhir adalah soal membangun arah geopolitik dunia yang stabil dengan menciptakan kondisi dimana setiap aktor tetap tidak mengubah bahkan berupaya mengubah status qou AS terhadap politik global (Art, 2003).

Sebagaimana tiga poin yang telah disebutkan diatas, jika diuraikan mendalam maka grand strategy AS 
mengarah pada pencapaian strategis yang lebih luas. Melalui Indo-Pasifik AS mengarahkan grand strategy untuk tujuan melindungi kepentingan nasionalnya beserta negara-negara yang menjadi aliansinya. AS membangun jaringan hubungan diplomatik dengan India guna meningkatkan kembali pengaruh hubungan militer dan kekuatan ekonomi. Memastikan akses terhadap sumber daya alam, perluasan target pasar, hingga jalur perairan internasional samudera Hindia dengan memastikan keamanan terhadap Sea Lines of Communication (SLOCs). Dari urgensitas yang dihadapi AS saat ini, domain maritim menjadi hal yang mendasar guna meyakinkan kembali akan dominasi kekuasaan yang telah berlangsung sejak abad ke-20 (Blackwill \& Tellis, 2015). IndoPasifik memberikan landasan geografis bagi strategi AS dalam melakukan pemetaan terhadap masa depan kekuatan global. Dengan demikian mempertahankan pengaruh di Indo-Pasifik merupakan upaya sekaligus pencapaian terhadap grand strategy AS (Tellis, 2017).
Sebagai negara hegemon, penguasaan atas wilayah geografis merupakan keutamaan guna mendukung pencapaian geostrategi. Sebagaimana di awal kepemimpinannya, Donald Trump melihat disukursus Indo-Pasifik merupakan agenda utama dari pencapaian "America First National Security Strategy". Penguasaan terhadap kawasan tersebut meghadirkan ruang bagi AS dalam menciptakan hambatan struktural terhadap Tiongkok. Adapun yang dianggap penting selanjutnya dari grand strategy AS yakni penekanan kembali terhadap kehadiran militer (Tatsumi, 2017). Pergerakan Armada Angkatan Laut AS terbukti cukup efektif dalam meberikan penekanan fisik terhadap kepatuhan setiap negara di kawasan terhadap hukum internasional. Hal tersebut penting untuk dilakukan mengingat Tiongkok telah menjelma sebagai negara dengan kekuatan militer yang sekarang ini memiliki basis kekuatan di LCS. Kemudian, mengulas kembali hasil pertemuan Quadrenniel Defence Review 2010, AS telah menyatakan 
aliansi Jepang Australia dan India adalah untuk menjaga stabilitas kawasan. Sejalan dengan hal tersebut proyeksi pada tahun 2020 diharapkan sekitar 60\% dari Angkatan Laut AS mampu beroperasi secara maksimal terutama di kawasan perairan tersebut (Marcus. Jonathon, 2012).

Sebagai lagkah awal, forum QSD merepresentasikan kepentingan Washington dimana forum tersebut terikat dalam kesepakatan multilateral yang dibangun berdasarkan blok aliansi pertahanan. Menjalankan fungsinya sebagai jalur perairan internasional, AS dalam diskursus Indo-Pasifik pada dasarnya menghendaki terbentuknya konektivitas dengan negara-negara di sub kawasan lainya (Cronin, 2013). Sebagai titik pertemuan antara samudera Pasifik dan Hindia, apa yang harus dipahami dari Indo-Pasifik adalah tentang bagaimana grand strategy AS mengartikulasikan hal tersebut ke dalam ruang geopolitik yang saling terikat satu dengan lainnya. Tidak hanya karena penting untuk strategi keamanan, namun hal tersebut juga berdampak pada perputaran ekonomi dunia yang menawarkan pada prospek baru dari skema perdagangan global (Shyam, 2011). Adapun hal tersebut menjadi konsekuensi logis dimana India saat ini hampir seluruh negara-negara di kawasan juga mengalami pertumbuhan ekonomi yang cukup menjanjikan terutama pasca berakhirnya perang dingin.

\section{"Free Open Indo-Pacific" VS One}

\section{Belt On Roads}

Kemjuan pesat perekonomian India yang juga merupakan simbol kekuatan dominan di samudera Hindia, telah menjadi daya tarik tersendiri bagi AS. Terbukti sejak akhir Perang Dunia II, walaupun belum terakumulasi secara menyeluruh, AS telah terlebih dahulu memberikan perhatian khusus atas situasi yang berkembang di samudera Hindia. Melihat potensi yang begitu besar, AS tidak hanya menjadikan samudera Hindia sebagai basis pergerakan pasukan AS menuju Timur Tengah, namun juga sebagai laju perekonomian dunia. Dengan begitu yang terpikirkan oleh pemerintah Trump saat ini adalah bagaimana mengusung Indo-Pasifik 
sebagai zona liberal intitusionalisme. Adapun keuntungan mutlak yang bisa ditawarkan dari Indo-Pasifik adalah tentang bagaimana merealisasikan skema "Free Open Indo-Pacific" (FOIP). Faktor geografis Indo-Pasifik yang merupakan penggabungan antara samudera Pasifik dan Hindia menjadi akses strategis sebagai penunjang regulasi demi mempermudah kerja sama ekonomi kawasan (Kanehara, 2018).

Upaya tersebut memastikan pencapaian situasi keamanan kawasan yang lebih stabil, kerja sama ekonomi berbasis pasar bebas, serta kepatuhan setiap negara terhadap hukum internsional. Ketiga hal tersebut menunjukan bahwa pentingnya samudera Hindia dalam grand strategy AS merupakan keutamaan dari apa yang sebelumnya terlewatkan oleh Asia-Pasifik (English, 2012). Jaminan atas konsep FOIP memberikan keleluasaan dalam setiap diskusi mengenai perwujudan kawasan yang bebas dan terbuka. Dalam hal ini komitmen AS terbukti cukup memberikan kepastian dengan menjadikan Indo-Pasifik sebagai basis pergerakan barang dan jasa yang menunjang bagi pertumbuhan kerja sama ekonomi kawasan. Mega proyek OBOR menghadirkan tantangan besar bagi tatanan liberal internasionalisme AS saat ini, dimana hal tersebut merupakan langkah keberhasilan perluasan Sino-centric melalui pengembangan iklim investasi dan perdagangan di banyak negara Asia Tengara, hingga Afrika (McDaniel, 2012).

Dengan melihat kebangkitan Tiongkok sebagai sebuah ancaman terhadap stabilitas hegemoni, maka yang kemudian hendak dibentuk dari grand strategy AS adalah menumbuhkan optimisme negara di kawasan dalam mewujudkan visi IndoPasifik sebagai tatanan kawasan yang inklusif dan terbuka bagi kepentingan bersama negara di kawasan. Diskursus FOIP mencoba membangun platform khusus tentang bagaimana mengupayakan jalan tengah. Penolakan terhadap upaya unilateralisme Tiongkok dikawasan terkait mega proyek OBOR dilakukan dengan memberikan kemudahan akses geograifs dengan membuka jalur lintas 
penghubung samudera Pasifik dengan

Hindia dimana setiap negara secara kolektif mengambil peranan penting dalam pembangunan kawasan selanjutnya.

Dengan demikian menjadikan kawasan yang terbuka serta memberikan kebebasan bagi aktivitas perekonomian dunia, menghadirkan daya tarik tersendiri dalam dinamika politik internasional. Menjaga keseimbangan terhadap aktor-aktor dominan dikawasan seperti Rusia, Korut, Korsel, Jepang, Australia, India, Pakistan, ASEAN bahkan Tiongkok sekalipun, tentunya memiliki dampak yang sangat kuat bagi masa depan hegemoni AS. Mengesampingkan peran Tiongkok yang kemudian secara totalitas menganggap hal tersebut sebagai acaman terhadap tolak ukur pencapaian serta keberhasilan hegemoni AS merupakan hal yang keliru (Ellsworth, Goodpaster, \& Hauser, 2000). Disilah letak pesan tersirat yang ditawarkan AS dimana cara terbaik membatasi dominasi serta pengaruhnya Tiongkok di kawasan tidak lain ditempuh dengan mengikutsertakan Tiongkok secara aktif terlibat dalam setiap mekanisme yang dibentuk tanpa pengecualian. Pemahaman inilah yang menjadi argumentasi dasar soal betapa pentingnya mengintegrasikan samudera Pasifik dan Hindia ke dalam tatanan yang terintegrasi (Blackwill \& Tellis, 2015).

\section{Tantangan Masa Depan Keamanan}

\section{Maritim Indo-Pasifik}

Keamanan maritim pada umumnya dipahami sebagai sebuah situasi ataupun tujuan akhir dari upaya tentang pemeliharaan perdamain serta stabilitas keamanan kawasan khususnya di zona maritim. Dimaksud dengan pemeliharaan perdamain serta keamanan sudah termasuk didalamnya mengenai SLOCs, proteksi keamanan di luat, hingga penanganan tindak kejahatan maritim. Namun ketika cakupannya diperbesar maka pengamanan sumber daya kelautan, sekaligus akses terhadap sumber biota laut, serta perlindungan terhadap lingkungan juga termasuk kedalam zona keamanan maritim (Feldt, Roell, \& Thiele, 2013). Memasuki era kontemporer, perluasan ancaman non- 
militer turut berpengaruh terhadap konsep pemahaman kemaritiman itu sendri. Hal ini diperjelas ketika berbagai tindakan seperti imigran gelap, terorisme maritim, penyelundupan narkotika, pembajakan, bencana alam, hingga Ilegal

\section{Unreported Unregulated}

Fishing sekarang ini termasuk dalam cakupan keamanan maritim. Adapun perkembangan ancaman nontradisional tersebut pada umumnya merupakan tolak ukur dalam meninjau ulang konsep keamanan maritim terlebih memasuki era Indo-Pasifik (Marsetio, 2014).

Sejauh ini dunia telah menyaksikan bahwa lebih dari 90\% transaksi perdagangan global memadati hampir keseluruhan titik wilayah jalur perairan strategis dunia. Dalam hal tertentu, kesepakatan negara terkait konsensus soal bagaimana melakukan pengawasan terpadu dan menyeluruh terhadap keamanan maritim baik di level kawasan maupun global telah terbentuk melalui platform yang sebelumnya telah diberlakukan. Namun ironinya platform yang ada tidak serta merta mampu mengakomodasi atau bahkan membatasi perilaku negara-negara dominan di kawasan. Hukum laut internasional diatas kesepatakan UNCLOS nampaknya juga belum pada taraf yang mempu mengikat dan menjamin setiap prilaku negara untuk tunduk pada aturan yang berlaku.

$$
\text { Adapun perkembangan }
$$
paradigma regionalisme mengalami kemajuan begitu pesat dalam beberapa dekade terakhir tidak jarang menemui kebuntuan ketika pembahasan persoalan kemaritiman (Brewster, 2010). Jauh sebelum istilah IndoPasifik ramai diperbincangkan publik, sejumlah negara di Asia telah terlebih dahulu membentuk kerja sama yakni Regional Cooperation Agreement on Combating Piracy and Armed Robbery against Ships in Asia (ReCAAP). Melihat urgensitas yang terjadi pada domain maritim, Angkatan Laut India memulai inisiatif dengan mengadakan The Indian Ocean Naval Symposium (IONS). Dalam pertemuan tahunan yang diikuti oleh sejumlah perwakilan seluruh pimpinan Angkatan Laut negara-negara di kawasan, 
kecendrungan lebih membahas seputar masalah keamanan serta keselamatan pelayaran, dimana sejumlah isu seperti bencana alam, berbagai bentuk penyelundupan serta aktivitas illegal. Indian Ocean Rim Association (IORA) dimana penekanannya lebih mengarah pada upaya perwujudan tata kelola kawasan sebagaimana yan juga tercermin dalam ASEAN Regional Forum (ARF).

Namun berbagai bentuk pertarungan kepentingan sejumlah negara besar dikawasan menghantarkan pada kerumutin tersendiri. Mutual trust sebagaimana yang ramai diperbincangkan sebelumnya melalui rezim internasional ternyata tidak lagi dapat seutuhnya menghantarkan setiap aktor dikawasan untuk berada pada visi yang sejalan (Gujar, Ghosh, \& Yan, 2014). Selain bertumpu pada paradigma regionalisme, integrasi dalam cakupan geografis sebagai wujud dari diskursus Indo-Pasifik turut berdampak pada perubahan pemaknaan konsep kemanan maritim. Diskursus IndoPasifik menghadirkan tantangan baru bagi eksistensi pemahaman terhadap masa depan kemanan maritim selanjutnya. Sejauh ini, Indo-Pasifik turut mempengaruhi setiap sudut pandang negara di kawasan terhadap SLOCs hingga kebebasan dalam bernavigasi. Fenoma tersebut menjadi penting untuk dipahami lantaran hingga saat ini, negara-negara litoral Indo-Pasifik masih menyisahkan warisan konflik Asia-Pasifik yang bermuara pada pertarungan kepentingan geostrategi sejumlah negara-negara di kawasan (Gujar, Ghosh, \& Yan, 2014).

Persaingan strategis ASTiongkok setidaknya telah memaksa dunia internasional untuk menyaksikan sesuatu hal yang hampir selalu terjadi secara simultan lantaran konflik kepentingan berlangsung disegala aspek tanpa terkecuali domain maritim. Pertaruhan akan keamanan maritim terkadang juga menghadirkan sebuah paradoksal, seperti dalam beberapa hal tertentu dimana polarisasi pembagunan kerja sama justru ruang bagi persaingan strategis ASTiongkok. Hal tersebut sebagai gambaran bahwa domain maritim tak ubahnya ajang pertarungan yang mana 
keberpihakan AS terhadap India sama halnya strategi membendung dominasi Tiongkok baik dari segi ekonomi maupun militer. Hal tersebut sama halnya dengan penekanan terhadap bebas bernavigasi diatas LCS dianggap sebagai bentuk nyata terhadap penolakan AS terhadap klaim sepihak Tiongkok di LCS. Hal inilah yang juga menjadi alasan kuat AS akan pentingnya membangun aliansi strategis dengan India, Jepang, dan Australia (Ghosh P. , 2011).

Meletakan Indo-Pasifik diatas kepentingan status quo, samahalnya dengan memberikan praktik keleluasaan bagi hegemoni AS. Penting dipahami bahwa apa yang kemudian hadir ditengah perwujudan keamanan maritim Indo-Pasifik adalah upaya menekan proyeksi kekuatan Tiongkok di kawasan dengan cara menghadirkan sebuah tatanan baru yang disepakati secara konsensus. Pertarungan strategis AS-Tiongkok meluas sebagai bantuk ancaman lain dari perkembangan ancaman nontradisional (Chellaney, 2018). Menteri Luar Negeri AS John Kerry di era pemerintahan presiden Barack Obama telah menegaskan bahwa jaminan atas keamanan maritim pada dasarnya akan bermuara pada stabilitas ekonomi, kontrol terhadap lingkungan strategis. Atas usulan tersebut, AS di masa pemerintahan Obama berangapan bahwa tak ada jalan lain bagi AS untuk segera mengdeklarasikan kebijakan global rebalance of Asia guna menghadirkan proyeksi jangka panjang dalam merespon fenomena kebangkitan Tiongkok (Dobell, 2018). Namun, dukungan terhadap stabilitas keamanan tidak berarti dukungan penuh terhadap status quo. Hal inilah yang juga menghadirkan dilema tersendiri bagi keamanan maritim disaat pemenuhan kepentingan AS di Indo-Pasifik sama dengan ancaman bagi eksistensi Tiongkok (Dobell, 2018). Hal mendasar dari fenomena Indo-Pasifik yang didalamnya juga meliputi integrasi kerja sama ekonomi tentunya menjadi sesuatu hal yang melekat dalam pembahasan keamanan maritim. Dengan ini maka, hegemoni AS menjadi kunci terkait pertanyaan selanjutnya mengenai apakah hal tersebut juga menjadi bagian dalam 
operasi penolakan terhadap proyeksi global Tiongkok terkait maritime silk roots economic belt atau OBOR (Swaine, 2018). Dengan demikian mustahil nampaknya jika diskursus Indo-Pasifik tidak menghantarkannya pada perubahan tantangan dan peluang dari konsep keamanan maritim. Terlepas dari dimensi ancaman nontradisional setuju atau tidak, keamanan maritim Indo-Pasifik dipastikan akan berada dibawah hegemoni AS. Hal tersebut tercermin ketika AS hedak menjadikan samudera Hindia sebagai basisi dominasi militer India (Swaine, 2018).

Menjadi kekuatan dominan di kawasan, AS memproyeksikan fenomena tersebut sebagai peluang bagi India melakukan perluasan geostrategi yang pastinya akan beririsan dengan mega proyek Tiongkok terkait realisasi OBOR. Diskursus Indo-Pasifik tidak secara general membenarkan sumber ancaman non-tradisional seperti sebagaimana yang berkembang sejak berakhirnya perang dingin. Tidak secara langsung berada pada posisi saling kontak senjata, namun skema balancing power tetap berlangsung menjadi ancaman nyata sebagai warisan konflik Asia-Pasifik sebelumnya. AS sebagaimana contohnya tetap melakukan gelar pasukan melalui kehadiran militer. Sebagai wujud dari operasi keamanan maritim, hegemoni AS memposisikan diri sebagai pihak yang memiliki kewenangan untuk mengambil tindakan tegas terhadap segala bentuk pelanggaran yang terjadi diwilayah tersebut (Izuyama \& Kurita, 2017).

\section{Indo-Pasifik Menuju Trasnformasi Geopolitik Kawasan \\ Pada prinsipnya Indo-Pasifik} bertumpu pada persoalan mendasar tentang bagaimana menjawab tantangan akan percepatan integrasi ekonomi yang diiringi dengan perubahan struktur keamanan kawasan. Layaknya sebuah diskursus, tentu persoalan pembentukan kembali tatanan di kawasan menjadi salah satu keutamaan yang diciptakan melalui grand strategi AS. Dalam sudut pandang geopolitik, representasi India merupakan kekuatan baru yang mempu berperan sebagai balancing bagi Tiongkok. Bagaimanapun Indo- 
Pasifik mengemas sebuah dinamika hubungan baru antara Tiongkok dan India, dimana kerjasama, koeksistensi, persaingan, hingga konfrontasi menjadi salah satu tantangan strategis terhadap penguasaan AS di abad ke21. Hal tersebut menjadi solusi yang diprakarsai oleh AS ketika persaingan strategis diantara keduanya sejauh ini telah berpengaruh besar terhadap struktur keamanan kawasan (Medcalf, 2017). Dalam prespektif Australia, konflik LCS tetap menjadi kekhawatiran AS yang dengan kata lain merupakan jalur strategis maritim Pasifik barat. Guru Besar The Australian National University (ANU) David Brewster secara gostrategi, LCS bagi Tiongkok merupakan kunci utama penguasaan terhadap jalur pedagangan internasional, hingga alur transportasi energi dunia (Blaszczyk, 2018).

Peningkatan kapabilitas militer Tiongkok seolah membuat upaya AS dalam mengedepankan prinsip freedom of navigation menjadi mustahil untuk diwujudkan. Polemik tersebut masih harus ditambah dengan proyeksi ekonomi global Tiongkok terkait OBOR (Pandey, 2018 ).
Pertarungan geopolitik menjadi hal yang tidak dapat dihindari, warisan problematika Asia-Pasifik mengharuskan AS berhadapan dengan visi unilateralisme Tiongkok di Asia. Diskursus Indo-Pasifik, AS membuka peluang besar dalam membendung pengaruh Tiongkok. Mengambil langkah progresif dengan kembali menekankan pada stabilitas keamanan kawasan, jelas Tiongkok tetap merupakan bagian integral dari geopolitik Indo-Pasifik. Baik AS maupun India menyadari bahwa bagaimana pandangan Beijing tetap bersebrangan dengan aliansi AS terlebih soal Indo-Pasifik. Terkait hal tersebut, fenomena perang dagang ASTiongkok belakangan merupakan pembuktian bahwa keduanya berada pada dilematis tersendiri ketika persangingan strategis menjadi gambaran atas keseluruhan dari bentuk diplomasi kedua negara tersebut.

Adapun perlu diingat, sejauh ini Tiongkok adalah salah satu mitra dagang terbesar India. pertemuan Perdana Menteri Narendra Modi bersama Presiden Tiongkok Xi Jinping tepatnya April 2018 lalu berujung pada 
penandatanganan kontrak kerja sama senilai 84.44 Milyar USD. Dibandingkan tahun sebelumnya, bahwa 2018 telah terjadi peningkatan sejumlah $18.63 \%$. Namun apa yang mungkin diharapkan oleh Tiongkok masih sulit menjadi kenyataan ketika pada pertemuan the Shanghai Cooperation Organisation (SCO) Menteri Luar Negeri India Sushma Swaraj sebaliknya menolak untuk mendukung ambisi Tiongkok dalam mega proyek OBOR dihadapan seluruh negara anggota SCO lainnya seperti Russia, Pakistan, Kazakhstan, Kyrgyzstan, Tajikistan and Uzbekistan, yang telah jauh hari sebelumnya menyatakan dukungan terhadap OBOR (Deb, 2018). Penolakan tersebut secara simbolis menunjukan bahwa keberlangsungan diskursus Indo-Pasifik yang secara otomatis turut menyertakan keterlibatan India, menjelma sebagai kekuatan dominan di samudera Hindia (Upadhyay, 2014).

India tentu tidak akan terlepas dari forum QSD yang menjadi platform khusus guna mengimbangi dominasi ekonomi dan militer
Tiongkok. Forum tersebut menjadi hal yang penting bagi AS disaat Tiongkok sendiri memiliki pengaruh besar terhadap geopolitik Asia-Pasifik. Transformasi geopolitik menjadi konsekuensi logis ketika diskursus Indo-Pasifik sama dengan upaya untuk membatasi ruang gerak Tiongkok melalui perluasan cakupan geografis dengan mengikutsertakan samudera Hindia. Meleburnya Samudera Hindia ke dalam sebuah tatanan yang secara konseptual disepakati secara konsensus oleh negara-negara di kawasan (Dobell, 2018 ). Penguasaan terhadap aspek geografis dalam diskursus Indo-Pasfik tentu menjadi pembuktian terhadap penegasan kembali hegemoni AS. Bertumpu pada asumsi teori geopolitik dimana penguasaan kontrol terhadap geografis yang dalam hal ini merupakan samudera Hindia, menjadi sebuah simbol pendudukan atas kekuasaan serta eksistensi hegemoni AS saat berhadapan dengan fenomena kebangkitan Tiongkok.

Hal tersebut dibuktikan ketika AS mengganti nama U.S. Pacific Command (USPACOM) menjadi U.S. 
Indo-Pacific

Command

(USINDOPACOM) pada akhir Mei 2018 lalu. Disamping itu, Menteri Pertahanan AS James N. Mattis juga melakukan rotasi pergantian jabatan dengan menyerahkan kepemimpinan dari Admiral. Phil Davidson kepada Admiral Harry Harris sebagai komandan pertama dalam sejarah perubahan nama USPACOM menjadi US-INDOPACOM. Sejak dibentuk tahun 1978, USPACOM dalam sejarahnya merupakan ujung tombak dari pergerakan militer AS terhadap penciptaan kondisi di sepanjang samudera Pasifik. Bagi Mattis, Perubahan US-INDOPACOM merupakan respon terhadap meningkatnya konektivitas antara samudera Hindia dan Pasifik. Hal ini menggambarkan komitmen AS dalam meningkatkan stabilitas di kawasan Indo-Pasifik dengan mempromosikan kerja sama keamanan, mendorong prospek perdamaian, mencegah agresi, dengan pendekatan yang berdasarkan pada kemitraan strategis, penguasaan secara menyeluruh, hingga kesiapan militer (Pacom.mil, 2018 ).
Selain itu, US-INDOPACOM menandakan perubahan berbagai sendi-sendi geopolitik AS di kawasan yang secara perlahan mulai dirasakan. Adapun model aliansi sebagaimana layaknya QSD tidak lagi sebatas upaya semu yakni melindungi diri dari acaman militer negara lain. Lebih kepada penekanan struktural yang beririsan langsung dengan problem sistemik di Asia-Pasifik, jarak sekaligus perbedaan geografis antara India, Australian dan secara keseluruhan menempati titik sentral penguasaan geografis AS terhadap kawasan Indo-Pasifik. QSD sejak beberapa tahun sebelumnya dipersiapkan sebagai penyatuan visi dan pandangan negara aliansi AS dalam merespon bentuk-bentuk ancaman unilateralisme Tiongkok (Sokinda, 2015).

Sejak berakhirnya perang dingin, tren yang berkembang di AsiaPasifk adalah sebagai kawasan pusat kecenderungan aktivitas dunia internasional. Namun hal tersebut menimbulkan paradoks tersendiri dimana merebaknya fenomena integarasi dan regionalisme ekonomi 
berbanding terbalik dengan kondisi keamanan di kawasan. Ancaman terhadap stabilitas keamanan terus berlangsung, alhasil ekonomi menjadi modal logistik untuk menopang pegeluaran budget anggaran pertahanan. Asia-Pasifik pada tahun 2015 tercatat menjadi wilayah dengan pengeluaran anggaran untuk belanja alutsista terbesar setelah Eropa, dan benua Amerika (Yahuda, 2000). Pentagon jelas telah mengingatkan bahwa fenomena tersebut bahwa geopolitik yang berlangsung memaksa negara untuk kembali mengulang dinamika perlombaan senjata sebagaimana yang terjadi di era perang dingin. Hal tersebut pada intinya merujuk pada pembangunan kapabilitas pertahanan Tiongkok secara besar-besaran sejak tahun 2013 (Mapp, 2014). Memasuki tahun 2018, dimana anggaran awal pertahanan Tiongkok mencapai 175 MilyarUSD atau setara dengan 2,5 Juta Triliun Rupiah (Shepherd \& Martina, 2018).

Sengketa LCS, polemik uji coba senjata nuklir Korut, hingga fenomena kebangkitan Tiongkok menjadi gambaran struktural akan kebuntuan geopolitik yang tengah berlangsung di Asia-Pasifik. Adapun sejarah kali ini berkata lain, dibawah rezim Trump fondasi interaksi negaranegara di kawasan sedikit bergeser. April 2018 merupakan pertamakalinya pemimpin kedua negara antara Korea Selatan dan Utara sejak meletusnya perang Korea di tahun 1953. The two leader Korean Summits antara Kim Jong-un dan Moon Jae-in yang berlangsung di perbatasan ke dua negara tersebut mengawali sejarah baru bagi prospek perdamaian Semenanjung Korea sejak 65 tahun berlalu. Setidaknya ada tiga poin utama dari pertemuan tersebut pertama yakni soal pembatasan senjata nuklir Korut, kedua soal upaya penciptaan prospek perdamaian di Semananjung Korea, dan terakhir soal Demilitarized Zone (DMZ) (Panda, 2018).

$$
\text { Selanjutnya pertemuan Trump- }
$$
Kim summit, pada 12 Juni 2018 Donald Trump dan Kim Joung-un kembali menandakan awal perubahan bagi polarisasi hubungan antar negara di Indo-Pasifik. Atas pertemuan tersebut Trump mengklaim bahwa sekarang ini sebagai negara hegemon 
AS berpeluang besar untuk mengkonsolidasikan persahabatan baik antara Selatan dan Utara terlebih dalam mengatasi kepanjangan dari konflik masa lalu. Dengan ini sentimen positif Pyongyang akan membuka peluang bagi AS dan sekutunya termasuk Korsel dalam meredam agresivitas senjata nuklir Korut dimana hal tersebut selama ini menjadi risiko terbesar terhadap permaslahan utama terkait stabilitas keamanan khsusunya di sub-kawasan yakni Asia Timur (Mobrand, 2018 ). Bukan tanpa sebab, tentunya Pembentukan sentiment positif Korut dengan dunia barat merupakan bagian dari pencapaian grand strategy AS. Dalam sudut padang geopolitik terlihat jelas, bahwa guna mengawali era Indo-Pasifik, AS mulai kembali menyusun peta politik dimana sebelumnya berlangsung pertentangan besar-besar seolah tak dapat dibendung ketika setiap aktor berada pada misi pencapaian kepentingan nasional masing-masing di kawasan.

Satu pertanyaan mendasar dari merebaknya sentimen positif tersebut adalah dimana posisi Tiongkok dan apakah sentimen yang sama juga akan melanda hubungan AS -Tiongkok ?. Sejauh ini belum didapati kepastian terkait pertanyaan tersebut, namun dari sejumlah analis barat menyatakan bahwa jika pertanyaan siapa yang diuntungkan dan siapa yang dirugikan maka sangatlah jelas akan mengarah kepada Tiongkok. Perlu diingat kembali bahwa selama ini Tiongkok merupakan mitra strategis terdekat bagi Korut. Dalam beberapa kasus tertentu, Tiongkok seolah menjadi "payung" diplomasi bagi Korut ketika harus berhadapan dengan sanksi dari masyarakat internasional (Corr, 2017). Dengan demikian menjadi konsekuensi logis jika sentimen positif Korut terhadap dunia barat merupakan sasaran antaran AS untuk setidaknya meredam pengaruh Tiongkok. Agresifitas militer Korut merupakan kepanjangan dari kepentingan Tiongkok. Dengan ini Korut merupakan proxy Tiongkok dalam menghadirkan ancaman nyata bagi kekuasan barat dan hegemoni AS beserta negara sekutu lainnya.

Berangkat dari asumsi tersebut, tentu bukan perkara yang mudah 
dalam memecahkan kebuntuan yang terjadi selama ini. Membendung prilaku Tiongkok sebagaimana yang menjadi prinsip Indo-Pasifik, bukan berarti sepenuhnya menihilkan Tiongkok dari percaturan politik Internasional. Memahami hal mendasar dari bentuk dan sifat negara, diskursus Indo-Pasifik pada dasarnya juga hadir seraya mengingatkan kembali konsepsi pemahaman negara sebagai sebuah oragnisme yang hidup. Friedrich Ratzel dalam bukunya Political Geography (1897), berpendapat bahwa diskursus geopolitik tentu tidak dapat berdiri sendiri, darwinisme sosial adalah "ruh" utama yang menghantarkan pemikirannya dalam memahami mengapa negara perlu pertimbangan geopolitik (Tuathail, Dalby, \& Routledge, 1998). Retzel menegaskan bahwa negara tidaklah berbeda dengan organisme hidup yang harus bertahan guna menjaga eksistensinya di hadapan negara-negara lainnya. Layaknya organisme hidup, negara membutuhkan kekuasaan dan pengaruh guna menghindari proses "pembusukan" (Tuathail, Dalby, \& Routledge, 1998).

Menarik benang merah tersebut maka diskursus Indo-Pasifik tidak lain merupakan wujud nyata dari penekanan konsep geopolitik dibawah kendali supermasi AS sebagai negara hegemon. Perlu dipahami bahwa bentuk dari transformasi geopolitik dipastikan menjadi tolak ukur bagi eksistensi hegemoni AS dalam merestrukturisasi kembali peta pertarungan politik internasional (Jones, Jones, \& Woods, 2004). Lebih jauh, jika meletakan masalah pada kondisi struktural dari pemahaman alamiah tentang teori negara sebagai organisme yang hidup maka menjadi tantangan mendasar bagi AS ketika memposisikan kebangkitan Tiongkok sebagai warisan geopolitik sebelumnya. Urgensitas pembaharuan menjdi tujuan bagi AS guna mendorong diskursus Indo-Pasifik sebagai jawaban atas pertanyaan mendasar soal bentuk transformasi geopolitik selanjutnya. Dengan begitu arti penting samudera Hindia bagi AS lebih dari sebatas penghubung kepentingan, namun juga stabilisator 
kewasan yang berdampak besar bagi keberlangsungan eksistensi hegemoni AS (Gopalaswamy \& Ramachandran, 2017).

Perlu diingat bahwa menjadi hal yang tidak mungkin jika transformasi geopolitik yang hendak dihadirkan dari diskursus Indo-Pasifik adalah secara keseluruhan meninggalkan skema balance of power. Persaingan strategis antara ASTiongkok walau bagaimanapun akan tetap berlangsung, namun hal tersebut adalah tentang bagaimana AS mengawali diskursus Indo-Pasifik untuk tetap memberikan ruang bagi Tiongkok. Dibawah hegemoni AS, Tiongkok tetap memainkan perannya dalam percaturan politik internasional tanpa harus memperburuk situasi dengan menghadirkan kecemasan terhadap negara-negara di kawasan. Platform kerja sama keamanan kawasan tidak mengalami perubahan signifikan, semua difungsikan tetang bagaimana mengurangi risiko konflik kepentingan antar great power yang selanjutnya mempengaruhi transformasi geopolitik kawasan memasuki era Indo-Pasifik. Secara bersamaan dinamika yang berlangsung menuntut tanggung jawab penuh Tiongkok terhadap batasan norma regional dan hukum internasional, dengan tidak mengesampingkan sejumlah platform keamanan kawasan seperti EAS, ARF, ADMM-Plus dll (Izuyama, 2017).

\section{Kesimpulan}

Dipahami sebagai sebuah diskursus, tentu terminologi IndoPasifik memiliki cakupan aspek pemahaman yang cukup luas sebagaimana yang telah dijelaskan dalam subab-subab sebelumnya. Perluasan cakupan geografis dengan menyertakan peran penting India sebagai simbol kekuatan dominan samudera Hindia, tidak lain merupakan gambaran akan grand strategy AS dengan tujuan yakni membangun kembali aliansi kekuatan baru di Asia melalui platform QSD bersama Jepang, Australian, dan India. Dibawah inisiasi AS, maka dapat dikatakan agenda utama yang tersimpan dibalik diskursus IndoPasifik adalah upaya reformasi serta penguatan kembali hegemoni AS dari 
ancaman kebangkitan Tiongkok.

Mengusung konsep "free \& open Indo-Pasifik", dari aspek ekonomis AS mencoba mengusung kesepahaman tentang bagaimana memberikan kesempatan kepada negara-negara dikawasan untuk dapat saling mengambil keuntungan strategis guna memanfaatkan akses terhadap samudera Hindia guna menciptkan integrasi ekonomi kawasan yang lebih terpadu.

Dalam aspek geopolitik, maka diskursus Indo-Pasifik didalamnya juga tidak akan terlepas dari persaingan strategis, benturan kepentingan hingga perluasan serta penguasaan atas geografis sebagai basis kekuatan AS. Disamping itu, melalui Indo-Pasifik AS mengkombinasikan kembali penekanan terhadap hukum inernasional sebagai karekteristik arsitektur keamanan kawasan. AS dalam diskursus Indo-Pasifik menghendaki terbentuknya konektivitas dengan negara-negara dikawasan yang kemudian menjadi miniatur terhadap pembentukan arsitektur keamanan kawasan. Skema balance of power tentunya tidak dapat dipisahkan dari transformasi geopolitik Indo-Pasifik. Tolak ukur pencapaian diskursus Indo-Pasifik, hal tersebut dikarenakan memuat tiga pencapaian hegemoni AS, pertama soal bagaimana AS menempatkan India sebagai aktor baru dikawasan sekaligus berperan sebagai proxy kepentingan strategis AS dalam membendung Tiongkok, kedua yakni soal platform QSD yang memainkan fungsi layaknya sebagai bentuk alinasi baru di Asia yang menopang bagi kepentingan AS di kawasan, ketiga adalah tentang bagaimana praktik penguasaan aspek geografis yakni samudera Hindia sebagai representasi kekuatan

\section{Daftar Referensi}

Art, R. J. (2003). A Grand Strategy for America. United States of America: Cornell University Press.

AsiaTimes. (2017, November 9). IndoPacific' is new US name for Asia in slap at China, Asia Times. Retrieved from sia Times: http://www.atimes.com/article/ind opacificnewusnameasiaslapchina/

Basu, T. (2016 , Mei 27). India's Approach towards Indo Pacific Triangularity, Institute for Defence Studies and Analyses. Retrieved from IDSA.id: https://idsa.in/idsanews/indiasapproach-towards-indo-pacifictriangularity? $\mathrm{q}=$ print/

Blackwill, R. D., \& Tellis, A. J. (2015). Revising U.S. Grand Strategy 
Toward China, The Council on Foreign Relations (CFR). Council Special Report No. 72.

Blaszczyk, M. (2018, Juli 8). What should we make of the 'Indo-Pacific'?, What's in a name? Retrieved from Policy Forum: https://www.policyforum.net/poli cy-file-make-indo-pacific/

Brewster, D. (2010). An Indian Sphere of Influence in the Indian Ocean? Security Challenges, Vol 20, No 4, 2010.

Chellaney, B. (2018, Maret 24). A new order for the Indo-Pacific. Retrieved from Aspi Strategist: https://www.aspistrategist.org.au/ new-order-indo-pacific/

Corr, A. (2017, Juli 5). Chinese Involvement In North Korea's Nuclear Missile Program: From Trucks To Warheads. Retrieved from forbes.com: https://www.forbes.com/sites/and erscorr/2017/07/05/chineseinvolvement-in $\neg$ north-koreasnuclear-missile-program-fromwarheads-totrucks/\#326e75506f2f

Cronin. (2013). The Emerging Asian Power Web: The Rise of Bilateral Intra Asian Security Ties. Retrieved from Center for a New American Security: http://www.cnas.org/asianpowerweb)

Dar, S. S., \& Kalis, N. A. (2013). India's Strategic Response to War on Terrorism in Afghanistan, A Strategic Analysis. International Journal of Humanities and Social Science Invention (IJHSSI) Volume 2 Issue, 1-25.
Deb, A. (2018, Juli 8). Modi-Xi meet: What business they may discuss, . Retrieved from indiatimes.com: https://timesofindia.indiatimes.co $\mathrm{m} /$ business/india-business/modixi-meet-what-business-they-maydiscuss/articleshow/63936727.cm $\mathrm{s}$

Dobell, G. (2018 , April 11). The IndoPacific? The Quad? Please explain. Retrieved from aspistrategist.org:

https://www.aspistrategist.org.au/i ndo-pacific-quad-please-explain/

Dobell, G. (2018, Febuari 28). "The US and China: status quo powers in revisionist times. Retrieved from Aspi Strategist: https://www.aspistrategist.org.au/ us-china-status-quo-powersrevisionist-times/

Ellsworth, R., Goodpaster, A., \& Hauser, R. (2000). America's national Interests: A Report from The Commission on America's national Interests. Commission on America's National Interests.

English, P. (2012). The TransPacific Partnership: An Opportunity for American Leadership in the AsiaPacific Economy. The Ripon Forum, ed-3-2012, 40-56.

Escobar, P. (2017, Desember 7). The New Great Game moves from AsiaPacific to IndoPacific. Retrieved from Asia Time: http://www.atimes.com/article/ne wgreatgamemovesasiapacificindopacific/

Feldt, L., Roell, P., \& Thiele, R. D. (2013). Maritime Security: Perspectives for a Comprehensive Approach. ISPSW Strategy Series. 
Ghosh, M. (2017). India's Strategic Convergence with Japan in the Changing Indo-Pacific Geopolitical Landscape. EastWest Center, Asia-Pacific Bulletin No: 392, 1-17.

Ghosh, P. (2011). Security Challenges from Non-State Actors in the Indian Ocean. Strategic Trends, Vol, No 2011.

Godbole, A. (2017, Desember 9). What is IndoPacific and what is it not? Retrieved from Asia Times: http://www.atimes.com/indopacificindiaocean/

Godbole, A. (2017, December 17 ). What is IndoPacific and what is it not? Retrieved from Asiatimes: http://www.atimes.com/indopacificindiaocean/

Gopalaswamy, B., \& Ramachandran, A. (2017, Desember 19). The Shifting Balance of Power in the Indo Pacific. Retrieved from chinausfocus.com:

https://www.chinausfocus.com/pe ace-security/the-shifting-balanceof-power-in-the-indo-pacific

Gujar, G., Ghosh, P., \& Yan, H. (2014). A Strategy for Securing the Maritime Commons. Stimson Center.

Hagan, C. B. (1942). Geopolitics. The Journal of Politics, Vol. 4, No. 4, 478-490.

IDSA. (2016, Mei 27). India's Approach towards IndoPacific

Triangularity, Institute for Defence Studies and Analyses. Retrieved from IDSA, India Security Institute: https://idsa.in/idsanews/indias- approach-towards-indo-pacifictriangularity

Izuyama, M. (2017). Security in the Indian Ocean Region: Regional Responses to China's Growing Influence. East Asian Strategic Review.

Izuyama, M., \& Kurita, M. (2017). Security in the Indian Ocean Region: Regional Responses to China's Growing Influence. Goerge Washington University, East Asian Strategic Review.

Jones, M., Jones, R., \& Woods, M. (2004). An Introduction to Geopolitical Geography: Space, Place, and Politics. London: Routledge.

Jones, M., Jones, R., \& Woods, M. (2004). An Introduction to Political Geography : Space, place and politics. London : Routledge.

Kanehara, N. (2018, Maret 8). The Case for a New US-Japan Strategy: Why We Need a Free and Open Indo-Pacific. Retrieved from The Diplomat:

https://thediplomat.com/2018/03/t he-case-for-a-new-us-japanstrategy-why-we-need-a-free-andopen-indopacific/?allpages=yes\&print=yes

Mapp, W. (2014). Military Modernisation and Buildup in the asia pacific the case for restraint. RSIS Monograph No. 31.

Marcus. Jonathon. (2012, Juni 2). Leon Panetta: US to deploy 60\% of Navy Fleet to Pacific. Retrieved from bbc.com: 
http://www.bbc.com/news/worldus-canada- 18305750

Marsetio. (2014). Sea Power Indonesia. Bogor Universitas Pertahanan Indonesia: Unhan Press.

McDaniel, D. (2012). India, China and the United States in the IndoPacific region: coalition, co-existence or clash ? Australian Defence College.

Medcalf, R. (2017, Desember 31). Goodbye Asia-Pacific But Why The Sudden Buzz Over IndoPacific? Retrieved from South China Morning Post: http://www.scmp.com/weekasia/geopolitics/article/2137212/ will-india-turn-its-back-dalailama-appease-china

Medcalf, R., Heinrichs, R., \& Jones, J. (2011). Crisis and Confidence: Major Powers and Maritime Security in Indo-Pacific Asia. Sydney : Lowy Institute for International Policy.

Michel, D., \& Passarelli, R. (2014). Sea Change: Evolving Maritime Geopolitics in the Indo-Pacific Region . Washington, D.C.: Stimson Center.

Miller, J. B. (2017). The US-Japan-India Relationship: Trilateral Cooperation in the Indo-Pacific. Japan: Chicago Council on Global Affairs.

Mobrand, E. (2018 , Juni 2). America' Takes a New Meaning in South Korea, $\quad$ Retrieved from thediplomat.co: https://thediplomat.com/2018/07/ america-takes-a-new-meaning-insouth-korea/ 2 Juni 2018.
MoD. (2015, Oktober 15). U.S-India Malabar Exercise, Ministry of Defense Government of India. Retrieved from pib.nic.in: http://pib.nic.in/newsite/PrintRele ase.aspx ?relid=128755

MOFA. (2017, Agustus 22). Confluence of the Two Seas, the Parliament of the Republic of India. Retrieved from MOFA: http://www.mofa.go.jp/region/asi apaci

P.K.Ghosh. (2014). The Indo-Pacific Region and the Rise of Transnational Maritime Threats and Challenges. In D. Michel, \& R. Passarelli, Sea Change: Evolving Maritime Geopolitics in Indo-Pacific Regioan. New York: Stimson Center .

Pacom.mil. (2018, Juni 1). U.S. Pacific Command, U.S. Indo-Pacific Command Holds Change of Command Ceremony. Retrieved from Pacom.mil: www.pacom.mil/Media/News/Ne ws-Article-

View/Article/1535776/us-indopacific-command-holds-changeof-command-ceremony/

Panda, A. (2018, Juni 1). Why the KimMoon Summit at Panmunjom Matters: The summit between the two Koreas will set the tone for the Trump-Kim summit. Retrieved from Thediplomat.com: https://thediplomat.com/2018/04/ why-the-kim-moon-summit-atpanmunjom-matters/

Pandey, P. (2018 , Febuari 22). Emerging Geopolitics of the Indo-Pacific. Retrieved from Ipsa.org: https://wc2018.ipsa.org/events/co 
ngress/wc2018/paper/emerginggeopolitics-indo-pacific

Pitter, R. (2017, Oktober 13). The IndoPacific: Defining a Region. Retrieved from worldview.stratfor.com https://worldview.stratfor.com/art icle/indopacificdefiningregion

Rinehart, I. E., \& Elias, B. (2015). China's Air Defense Identification Zone (ADIZ). Congressional Research Service.

Scott, D. (2012). The "Indo-Pacific"New Regional Formulations and New Maritime Frameworks for US-India Strategic Convergence. Asia-Pacific Review, Vol. 19, No. 2.

Shepherd, C., \& Martina, M. (2018, Maret 5). China boosts defence spending, rattling its neighbours' nerves. Retrieved from UK,reuters.com:

https://uk.reuters.com/article/ukchina-parliament-defence/chinaboosts-defence-spending-rattlingits-neighbours-nervesidUKKCN1GG07D

Shyam, S. (2011). Mapping the Indo Pacific. Retrieved from cprindia.org http://www.cprindia.org/blog/bor ders/3574-mapping-indo-pacific

Sokinda, S. (2015). India's Strategy for Countering China's Increased Influence in the Indian Ocean. Indo-Pacific Strategic Papers, Australian Centre for Defence Research.

Swaine, M. D. (2018, Maret 2). Creating an Unstable Asia: the U.S. Free and Open Indo-Pacific Strategy.
Retrieved from Foreign Affairs: Carnegie Endowment for International Peace: http://carnegieendowment.org/20 18/03/02/creating-unstable-asiau.s.-free-and-open-indo-pacificstrategy-pub-75720

Tatsumi, Y. (2017, Desember 21). The US National Security Strategy: Implications for the Indo $\neg$ Pacific. Retrieved from The Diplomat: https://thediplomat.com/2017/12/t he-us-national-security-strategyimplications-for-the-indo-pacific/

Tellis, A. J. (2017, April 25). Protecting American Primacy in the IndoPacific. Retrieved from Carnegie Endowment for International Peace: http://carnegieendowment.org/20 17/04/25/protecting-americanprimacy-in-indo-pacific-pub68754

TheWhiteHouse. (2018, Maret 13). US $\neg$ India Joint Strategic Vision for the AsiaPacific and Indian Ocean Region. Retrieved from The White House: https://www.whitehouse.gov/thepressoffice/2015/01/25/us-indiajoint-strategic-visionasia $\neg$ pacific-andindian-oceanregion

Tuathail, G. O., Dalby , S., \& Routledge , P. (1998). The Geopolitics Reader. New York : Routledge.

Tuathail, G., Dalby, S., \& Routledge, P. (1998). The Geopolitics Reader. New York: Routledge.

Upadhyay, S. (2014). The Indo-Pacific \& the Indo-US Relations Geopolitics of Cooperation. IPCS 
Institute of Peace and Conflict

Studies.

Vijay, R. K., \& Sakhuja. (2014). Indo-

Pacific Region: Political and Strategi Prespective. New Delhi: Indian Council of World Affairs.

Yahuda, M. (2000). The International Politics of the Asia. London \& New York: RoutledgeCurzon. 